Prof. Corneliu-Liviu POPESCU

\title{
Decret sau decret-lege de instituire / de prelungire a stării de urgență / de asediu?
}

\section{Decree or decree-law establishing / extending the state of emergency / siege?}

\section{Cuvinte cheie}

Stare de asediu. Stare de urgență. Decret al Președintelui României. Act administrativ. Legiferare. Decret-lege.

\section{Key words}

State of siege. State of emergency. Decree of President of Romania. Administrative act. Legislative process. Decree-Law.

\section{Rezumat}

Decretul Președintelui României de instituire sau de prelungire a stării de asediu sau a stării de urgență este un act administrativ, subordonat legii. El nu este un decret-lege, deci nu este un act de reglementare primară, Președintele României nefiind legiuitor nici măcar în situații excepționale. Adoptarea de măsuri legislative prin astfel de decrete este neconstituțională.

\footnotetext{
Abstract

The Decree of the President of Romania establishing or prolonging the state of siege or the state of emergency constitutes an administrative act, subordinated to the law. It is not a decree-law, so it does not represent an act of primary regulation, the President of Romania not being a legislator even in exceptional situations. The adoption of legislative measures through such decrees is unconstitutional.
} 
1. Prin art. 1 din Decretul Președintelui României nr. 195/2020 privind instituirea stării de urgență pe teritoriul României ${ }^{1}$ a fost instituită starea de urgență pentru o perioadă de 30 de zile, începând cu data publicării oficiale, conform art. 8.

Ulterior, prin art. 1 din Decretul Președintelui României nr. 240/2020 privind prelungirea stării de urgență pe teritoriul României ${ }^{2}$ a fost menținută starea de urgență pentru o nouă perioadă de 30 de zile, începând cu ziua ulterioară împlinirii termenului inițial de 30 de zile, conform art. 9.

2. Prin capitolele V și VII din anexa nr. 1 la Decretul nr. 195/2020, respectiv prin capitolele VII și XI din anexa nr. 1 la Decretul nr. 240/2020 s-au adoptat măsuri cu caracter legislativ, și anume:

- s-a stabilit că nu curg ori se suspendă termenele de prescripție sau decădere în materiile civile lato sensu și că nu se aplică dispozițiile legislative în materie, precum și faptul că se suspendă curgerea prescripției răspunderii penale;

- s-a stabilit că nu se judecă și că nu se desfășoară activitatea de urmărire penală și cea a judecătorilor de drepturi și libertăți și a judecătorilor de cameră preliminară decât într-un număr extrem de redus de cauze, fiind abilitate colegiile de conducere ale Înaltei Curți de Casație și Justiție și ale curților de apel să stabilească aceste cauze, iar Consiliul Superior al Magistraturii să dea îndrumări în materie, precum și că această situație vizează și procedurile de competența Inspecției Judiciare;

- s-au instituit condiții și reguli procedurale speciale;

- s-au dublat termenele de răspuns la petiții și la cererile de informații de interes public.

3. Toate aceste norme sunt norme de reglementare primară, care au forță de lege, intervin în materii de natură legislativă și fac inaplicabile, modifică sau instituie reguli cu forță legislativă.

Rezultă că, prin conținutul său, cele două acte, de instituire, respectiv de prelungire a stării de urgență, sunt decrete-legi, adică acte ale Executivului, dar având forță juridică egală cu a legii.

Întrebarea care se naște imediat este dacă însă această situație este și constituțională. 
4. Potrivit art. 73 ("Categorii de legi") alin. (3) lit. g) și art. 93 ("Măsuri excepționale") alin. (1) din Constituție, regimul juridic al stării de urgență și regimul juridic al stării de asediu se reglementează prin lege organică, iar Președintele României instituie starea de urgență ori starea de asediu potrivit legii. Rezultă foarte clar că nu Președintele României reglementează regimul juridic al stării de urgență sau al stării de asediu, ci el doar o instituie, conform legii organice specifice.

De asemenea, conform art. 61 ("Rolul și structura") alin. (1) și art. 115 ("Delegarea legislativă") din Constituție, competența constituțională de a legifera (de a adopta norme de reglementare primară, imediat inferioare Constituției) aparține numai Parlamentului (care este unica autoritate legiuitoare a țării) și Guvernului (care este legiuitor delegat). Președintele României nu are nicio competență să adopte norme de reglementare primară, deci decretele sale nu pot avea niciodată forță de lege, adică nu pot conține norme de reglementare primară, nu pot modifica norme de reglementare primară, nu pot suspenda aplicarea normelor de reglementare primară, nu pot dispune inaplicabilitatea normelor de reglementare primară.

Încuviințarea de Parlament prin hotărâre a măsurii dispuse de Președintele României prin decret nu transformă în niciun caz decretul într-un act cu putere de lege, pentru că nici măcar hotărârea Parlamentului nu are o astfel de forță juridică.

De esența unei stări excepționale, cum este starea de urgență, este restrângerea excepțională a drepturilor omului, iar acest lucru nu poate fi făcut, potrivit art. 53 ("Restrângerea exercițiului unor drepturi sau al unor libertăți") alin. (1) din Constituție, decât prin lege.

Cu alte cuvinte, în situația în care se impune declararea stării de urgență sau a celei de asediu, competența constituțională a Președintelui României este exclusiv de a institui starea de urgență, prin decret contrasemnat de Primul-Ministru, și de a solicita Parlamentului încuviințarea măsurii adoptate. Președintele României nu stabilește însă regimul stării de urgență sau al stării de asediu ori restrângerea exercițiului drepturilor omului, acestea fiind rezervate legii sau ordonanței. Parlamentul nu face decât să încuviințeze măsura de instituire a stării de urgență sau de asediu, prin hotărâre, iar nu prin lege, așa încât niciodată decretul de instituire a stării de urgență sau de asediu nu are forță de lege și nu poate conține norme de reglementare primară. 
Cu referire concretă la conținutul decretelor de instituire, respectiv de prelungire a stării de urgență, prezintă relevanță și faptul că organizarea judiciară, procedura judiciară, materia penală și regimul general al proprietății se reglementează numai prin norme legislative, potrivit art. 73 alin. (3) lit. h), k), I) și m), art. 126 ("Instanțele judecătorești") alin. (2), art. 129 ("Folosirea căilor de atac") și art. 131 ("Rolul Ministerului Public") alin. (3) din Constituție.

5. Neavând forță de lege, actul de instituire sau de prelungire a stării de urgență sau de asediu nu este un decret-lege, ci este un decret (simplu, ordinar), adică un act administrativ, emis pe baza și în executarea legii și subordonat legii.

6. De altfel, ar fi de neconceput ca Legiuitorul Constituant, când a reglementat legiferarea / puterea legislativă (totuși, prima dintre activitățile / puterile statului) să fi ales două modalități tehnice total diferite pentru a o face: expres, pentru Parlament (legiuitorul titular) și pentru Guvern (legiuitorul delegat), dar implicit, ascuns, pentru Președintele României (un așa-zis legiuitor de criză). Normele de tehnică legislativă nu ne permit o asemenea concluzie.

Mai mult, chiar bunul-simț juridic ne spune, fără greș, că este imposibil ca funcția de legiferare în stat să rezulte doar implicit, pe calea unei eventuale interpretări forțate a textelor constituționale (de fapt, a tăcerii textelor constituționale).

7. Dacă am presupune, prin absurd, că decretele Președintelui României de instituire sau de prelungire a stării de urgență sau a stării de asediu ar putea să modifice, să completeze sau să suspende aplicarea normelor juridice conținute în legi sau ordonanțe, adică faptul că aceste decrete ar avea putere de lege (ar fi decrete-legi), deci că ar conține norme de reglementare primară, imediat inferioare Constituției, atunci ele (decretele) ar trebui supuse controlului de constituționalitate.

Este de principiu că ierarhia actelor juridice (instituție de drept substanțial), pentru a fi reală și efectivă, iar nu doar teoretică sau iluzorie, trebuie să se însoțească de un control de validitate (instituție de drept procedural), în cadrul căruia să se verifice conformitatea cu actul cu forță superioară a actului cu forță inferioară și, dacă este cazul, să fie sancționat cu 
lipsirea de efecte juridice actul cu forță inferioară care îl încalcă pe cel cu forță superioară.

Pentru actele de drept public, două sunt mecanismele fundamentale de verificare a respectării ierarhiei: controlul de constituționalitate și controlul de legalitate.

În structura ierarhică a surselor dreptului intern român, dacă ignorăm (pentru simplificarea expunerii) sursele dreptului internațional (convenționale, jurisprudențiale și de altă natură) care se integrează în ordinea juridică națională, precum și sursele jurisprudențiale naționale (constituțională și judiciară), regăsim pe numere mari trei paliere:

- blocul constituțional (Constituția și legile constituționale);

- legile și actele cu forță juridică de lege;

- actele administrative.

În principiu, controlul de constituționalitate vizează respectarea supremației Constituției (integrând legile constituționale) de legi și de actele cu forță juridică egală cu a legii (existând și situația de excepție în care controlul de constituționalitate se exercită chiar în interiorul blocului de constituționalitate, în sensul verificării constituționalității legilor constituționale, deoarece revizuirile constituționale au anumite limite, materiale și formale), în timp ce controlul de legalitate asigură respectarea superiorității legii față de actele administrative (inclusiv a supremației Constituției, neconstituționalitatea actelor administrative fiind doar o formă agravată de ilegalitate).

Controlul legalității actelor administrative ține de competența justiției (în concret, a instanțelor judecătorești de contencios administrativ), în timp ce controlul de constituționalitate se exercită numai de Curtea Constituțională, care este o jurisdicție de atribuție (specială și specializată).

Toate actele normative având forță imediat infra-constituțională, adică legile și actele cu putere de lege, sunt supuse controlului de constituționalitate. În concret, este vorba de:

- legi (organice sau ordinare);

- ordonanțele Guvernului (simple sau de urgență);

- regulamentele Parlamentului - ședințelor comune, Senatului și Camerei Deputaților (acestea au forță juridică egală cu a legii, fiind imediat infraconstituționale; materia nu este reglementată prin lege, ci prin regulament având forță de lege, pentru a respecta atât principiul autonomiei Parlamentului - în procesul de adoptare a regulamentului nu intervin subiecte exterioare, cum 
ar fi Guvernul, cu drept de inițiativă, sau Președintele României, cu drept de retrimitere sau de promulgare -, cât și principiul autonomiei fiecărei Camere - în procesul de adoptare a regulamentului propriu al unei Camere nu intervine cealaltă Cameră).

Este adevărat că există și acte care nu sunt imediat inferioare Constituției, ci sunt infra-legislative, dar care sunt supuse controlului de constituționalitate - avem în vedere hotărârile Parlamentului (altele decât cele de aprobare a regulamentelor), dar acest lucru nu infirmă teza conform căreia toate actele imediat infra-constituționale (legile și actele cu putere de lege) sunt obligatoriu supuse controlului de constituționalitate.

Dacă vreun act imediat inferior Constituției, deci având forță juridică egală legii, nu ar fi supus controlului de constituționalitate, ar însemna că principiul supremației Constituției, proclamat de art. 1 ("Statul român") alin. (5) din Constituție, ar fi teoretic și iluzoriu, iar nu real și efectiv. Pentru ca supremația Constituției să fie reală și efectivă, orice act cu forță de lege trebuie să poată fi supus controlului de constituționalitate și, dacă este cazul, invalidat pe motiv de neconstituționalitate. În caz contrar, neputând fi controlat și invalidat, respectivul act de drept pur intern (repetăm, discuția nu poartă și asupra surselor de drept internațional care sunt și surse ale dreptului intern) ar fi în realitate supra-constituțional, ceea ce este de neacceptat într-o democrație constituțională.

Cum niciun decret al Președintelui României nu este supus controlului de constituționalitate, înseamnă că el nu este imediat inferior Constituției, deci nu are putere de lege, ci este un act administrativ. Cenzura legalității decretelor Președintelui României revine instanțelor de contencios administrativ. Concluzia este valabilă fără discuție și pentru decretele de instituire sau de prelungire a stării de urgență sau a stării de asediu.

8. Dispozițiile art. 14 lit. $c^{1}$ ) - f) din Ordonanța de urgență a Guvernului nr. 1/1999 regimul stării de asediu și regimul stării de urgență $^{3}$ nu pot fi interpretate ca acordând Președintelui României o putere de legiferare prin decretul de instituire sau de prelungire a stării de urgență sau de asediu.

Textele au următoarea redactare:

"Decretul de instituire a stării de asediu sau a stării de urgență trebuie să prevadă următoarele:

$[\ldots]$; 
$\left.c^{1}\right)$ măsurile de primă urgență care urmează a fi luate;

d) drepturile și libertățile fundamentale al căror exercițiu se restrânge, în limitele prevederilor constituționale și ale art. 4 din prezenta ordonanță de urgență;

e) autoritățile militare și civile desemnate pentru executarea prevederilor decretului și competențele acestora;

f) alte prevederi, dacă se consideră necesare."

În măsura în care aceste dispoziții se interpretează în sensul că prin decretul de instituire a stării de urgență sau a stării de asediu se pot adopta norme cu putere de lege ori se poate suspenda aplicarea normelor cu putere de lege, se pot dispune limitări ale drepturilor omului care nu sunt prevăzute de lege, se pot stabili norme de procedură judiciară, se poate interveni în materie penală substanțială sau se poate suspenda activitatea instanțelor judecătorești ori a parchetelor, ele ar fi neconstituționale, prin raportare la art. 53 alin. (1), art. 61 alin. (1), art. 73 alin. (3) lit. g), h), k), I) și m), art. 93 alin. (1), art. 115, art. 126 alin. (2), art. 129 și art. 131 alin. (2) din Constituție.

Oricum, puterea de legiferare nu poate fi stabilită decât prin Constituție, iar nu prin lege.

În plus, textul nu satisface exigența convențională și constituțională de claritate, dimensiune a preeminenței dreptului (statului de drept). A permite Președintelui României să includă în decret orice măsuri ce pot fi luate și orice prevederi pe care le consideră necesare înseamnă a-i da o putere total discreționară, nelimitată și necenzurabilă, ceea ce contravine democrației constituționale.

9. Dacă era nevoie de adoptarea de măsuri precum cele cuprinse în cele două decrete indicate supra, nimic nu împiedica Guvernul să adopte o ordonanță de urgență ori, după caz, să iș̦i angajeze răspunderea pe un proiect de lege pentru modificarea cadrului normativ aplicabil stării de urgență, ceea ce ar fi respectat pe deplin exigențele constituționale ale art. 53 alin. (1), art. 73 alin. (1) lit. g), art. 114 ("Angajarea răspunderii Guvernului") alin. (1) și art. 115 alin. (4) și (6) din Constituție.

Este evident că existența unei situații excepționale justifică măsuri excepționale din partea autorităților publice, pentru rezolvarea situației și restabilirea normalității. Așa cum se afirmă în doctrină, legalitatea ordinară este înlocuită cu o legalitate excepțională, de criză, care conferă puteri excepționale 
autorităților publice. Acest lucru însă riscă să pună în pericol democrația constituțională și drepturile omului prin posibile abuzuri, de aceea legalitatea excepțională, care este oricum mult redusă față de legalitatea normală, trebuie respectată strict.

Într-un stat în care democrația, statul de drept și drepturile omului constituie valori fundamentale, respectarea strictă a legalității excepționale în situații de criză este esențială pentru prezervarea acestor valori.

10. În opinia noastră, prin toate normele indicate supra, cuprinse în decretele privind instituirea și, respectiv, prelungirea stării de urgență, Președintele României (care a emis decretele) și Primul-Ministru al Guvernului (care a contrasemnat decretele) au uzurpat puterea legiuitoare (a Parlamentului sau, prin delegare, a Guvernului), au interzis practic funcționarea justiției și a Ministerului Public și au afectat grav drepturile omului.

A uzurpa puterea legiuitoare, a suspenda practic puterea judecătorească și Ministerul Public (componentă a autorității judecătorești), a viola masiv drepturile omului, de șeful de stat și de șeful de Guvern împreună, constituie definiția clasică a loviturii de stat.

11. Aceste dispoziții manifest neconstituționale din cele două decrete trebuie anulate de instanțele de contencios administrativ, care pot fi sesizate de orice persoană interesată sau ar fi trebuit să fie sesizate, în temeiul art. 1 alin. (3) și (5) din Legea nr. 554/2004 a contenciosului administrativ ${ }^{4}$, de Avocatul Poporului și de Ministerul Public, interesul vătămat fiind unul public (ordinea constituțională), iar nulitatea fiind absolută.

12. Întrucât Președintele României și Primul-Ministru al Guvernului au încălcat atât rolul constituțional al Parlamentului, de unică autoritate legiuitoare a țării, cât și rolul constituțional al instanțelor judecătorești (puterii judecătorești) și al Ministerului Public, adică al autorității judecătorești, s-a născut un conflict juridic de natură constituțională.

Soluționarea conflictului este de competența Curții Constituționale, care ar fi trebuit să fie sesizată, în temeiul art. 146 ("Atribuții") lit. e) din Constituție, de substitutul președintelui Senatului, de președintele Camerei Deputaților și de președinta Consiliului Superior al Magistraturii. 
13. Lovitura de stat dată prin uzurparea puterii legiuitoare, prin suspendarea autorității judecătorești și prin violarea masivă a drepturilor omului ar trebui să determine Parlamentul, în calitatea sa de organ reprezentativ suprem al poporului român, să întreprindă de urgență măsuri pentru apărarea democrației constituționale, în sensul inițierii procedurilor constituționale pentru:

- tragerea la răspundere constituțională politică, prin demitere, și tragerea la răspundere constituțională penală, pentru înaltă trădare, a Președintelui României, potrivit art. 95 ("Suspendarea din funcție") și art. 96 ("Punerea sub acuzare") din Constituție;

- tragerea la răspundere constituțională politică a Guvernului (condus de Primul-Ministru), prin demiterea acestuia în urma adoptării unei moțiuni de cenzură, și tragerea la răspundere constituțională penală a Primului-Ministru al Guvernului, pentru fapte săvârșite în exercițiul funcției, conform art. 109 ("Răspunderea membrilor Guvernului"), art. 110 ("Încetarea mandatului") alin. (2) și art. 113 ("Moțiunea de cenzură") din Constituție.

14. În concluzie, în opinia noastră, decretul Președintelui României, contrasemnat de Primul-Ministru al Guvernului, de instituire sau de prelungire a stării de urgență sau a stării de asediu, este un simplu decret, adică un act administrativ (deci, infra-legislativ / subordonat legii), iar nu un decret-lege (adică nu este un act cu putere de lege, prin care să se adopte, să se completeze, să se modifice sau să se dispună neaplicarea unor norme de reglementare primară).

05.05 .2020

Materialul a fost publicat în revista online a Facultăţii de Drept, $\underline{A U B D-}$ Forum Juridic nr. 2/2020.

\footnotetext{
${ }^{1}$ Publicat în Monitorul Oficial al României, partea I, nr. 212/16.03.2020.

${ }^{2}$ Publicat în Monitorul Oficial al României, partea I, nr. 311/14.04.2020.

${ }^{3}$ Publicată în Monitorul Oficial al României, partea I, nr. 22/21.01.1999.

${ }^{4}$ Publicată în Monitorul Oficial al României, partea I, nr. 1154/07.12.2004.
} 